\title{
Fundamental Study on Large Deformations of Poles and Pole-Vaulting Characteristics
}

\author{
Atsumi OHTSUKI* and Shigemichi OHSHIMA*
}

\begin{abstract}
The record in pole-vaulting has been improved by using flexible fiberglass poles. In analysis of the dynamics of pole-vaulting, it is necessary to consider the high flexibility of poles. This paper deals with the large deformations of poles subjected to concentrated loads at two supporting points. A simple combination model is introduced which consists of a mass (vaulter) and a pole. Analytical solutions in terms of elliptic integrals are derived for vertical and horizontal displacements. Furthermore, time progress of pole deformation is investigated. From the results, it is clarified that the initial conditions(e.g., vertical and horizontal velocities of the vaulter) and the applied bending moment play important roles.
\end{abstract}

Key words: Pole-Vaulting, Pole Deformation, Bio-Motion, Simulation, Nonlinear Problem

\section{1.はじめに}

Fig. 1 に示すように, 棒高跳び競技は助走と踏 切による運動エネルギーをいったんポールの変 形エネルギーとして蓄え，その変形エネルギー を徐々に放出することによって高さを獲得する 競技であり，ポール素材が木製，竹製，ジュラ ルミン製，スチール製，そして現在のグラスフ アイバー製へと改善されるに従い跳躍記録が更 新されてきた.このように, 棒高跳びの記録向 上には競技者の技量に加え, ポールの素材やポ
一ル性能（特性）が大きく影響しているため, 棒高跳びの跳躍テクニックにはポールの材料特 性を精確に把握することが必要になっている. すなわち現今のグラスファイバーポールは極め て大きな変形を示す (Fig. 1 参照) ものであり, 従来のように跳躍者の訓練によっで゚ールの大 たわみ変形特性を体験的に知るだけでは効果的 な記録向上に結びつかないため, 工学的視点か らポールの有する変形特性を調べ, 高く跳ぶた めに如何に効率的に人間機能を発揮させるかの 研究が重要となってきた.

†原稿受付 1998年 3 月 3 日

1997年10月 スポーツ工学シンポジウム1997にて発表

*名城大学理工学部機械工学科

干468-8502 愛知県名古屋市天白区塩釜口 1-501

${ }^{*}$ Department of Mechanical Engineering, Meijo University, 1-501, Shiogamaguchi, Tempaku, Nagoya, Aichi, Japan (468-8502) 


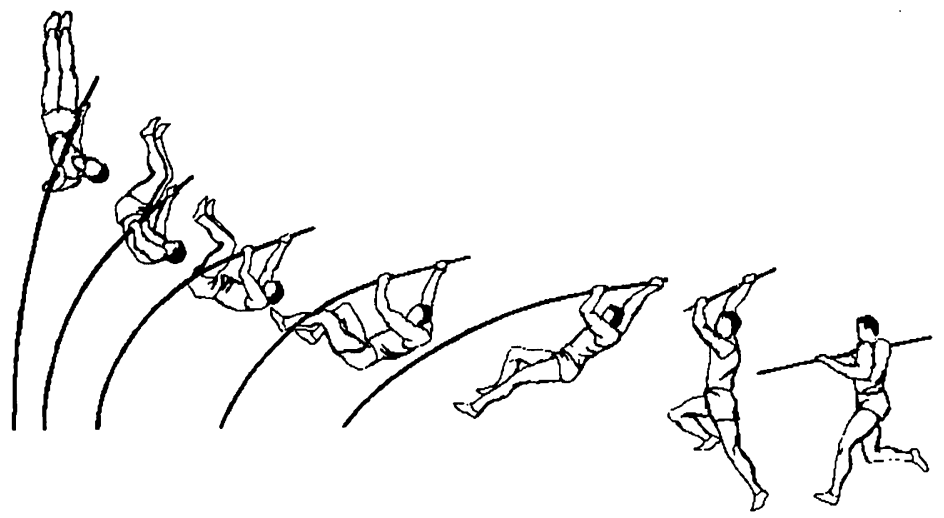

Fig. 1 An example of pole-vaulting with a fiberglass pole

棒高跳びの跳躍特性に関してはポールの弾性 エネルギーのみに注目した例1)やポール変形を近 似的に扱っている例233)がほとんどであり，ポー ルの大変形特性についてはポール先端の一点に 集中荷重とモーメントが作用した場合の解析例45) やポールの反転を考慮した著者らの解析理論 ${ }^{6}$ が ある. 本論文は, 跳躍者が備えている能力 (助走 力：初期水平方向速度，ジャンプ力：初期垂直 方向速度)および体重などから, 最高の跳躍高さ 獲得に最適なポール（長さおよび剛性）を選択 する際の目安を得るためにポールの大変形挙動 について検討を加えたもので，実際上のポール 負荷条件を十分考慮し，跳躍者の右手と左手の 保持部分に相当する二点に二つの集中荷重を作 用させた場合を非線形解析した。さらに，跳躍 者の運動については跳躍者を質点とする簡単な モデルを構築し，跳躍高さに及ぼすポール性能 (長さ, 剛性), 跳躍者能力 (走力等) などの影 響を動力学的に解析した。

\section{2.ポールの大たわみ变形理論解析}

棒高跳びのポールはグランドボックス内のポ 一ル一端を回転自由端 $\mathrm{A}$ とし, 他端 $\mathrm{C}$ および C から長さ $l$ の位置 Bに集中荷重を同時に受ける 大たわみはりとしてモデル化 (Fig. 2 参照) でき る。ただし，二つの荷重の大きさ，方向により， ポールに変曲点（点 D）が現れる場合と，現れ ない場合がある.Fig. 2 に示すように回転自由端

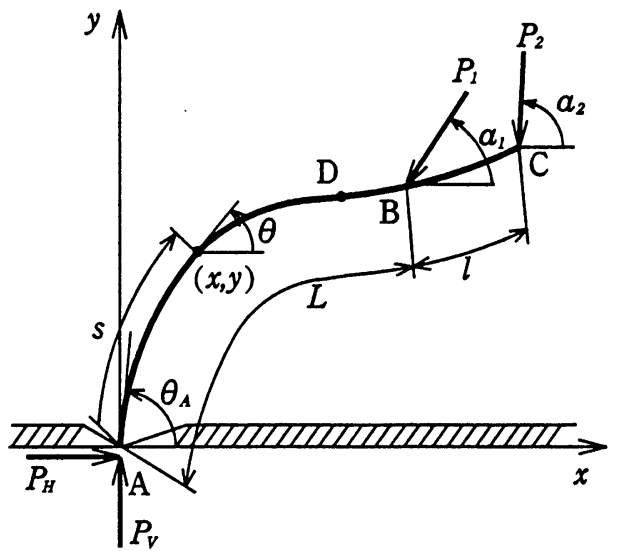

Fig. 2 Schematic configuration of pole-vaulting

$\mathrm{A}$ を座標原点とし, 水平方向に距離 $x$, 鉛直方向 に距離 $y$, たわみ曲線の円弧長さに $s$ をとり，た わみ角を $\theta$ で表す.さらにはりの曲率半径を $R$, 曲げモーメントを $M$ とすれば， $R, M, s, x, y$, $\theta$ の各量間に成り立つたわみの関係式は,はりの 縦弾性係数を $E$, 中立軸に関するはりの断面二 次モーメントを $I$ として

$$
\left.\begin{array}{l}
\frac{1}{R}=\frac{M}{E I}=-\frac{d \theta}{d s} \\
d y=d s \cdot \sin \theta, \quad d x=d s \cdot \cos \theta
\end{array}\right\}
$$

点 $\mathrm{B}$ および自由端 $\mathrm{C}$ が水平方向に対してそれ ぞれ角度 $\alpha_{1}, \alpha_{2}$ をなす斜め集中荷重 $P_{1}, P_{2}$ を同 時に受けるとき，回転自由端 $\mathrm{A}$ における鉛直方 
向反力 $P_{V}$, 水平方向反力 $P_{H}$ は

$P_{V}=P_{1} \cdot \sin a_{1}+P_{2} \cdot \sin a_{2}, P_{H}=P_{1} \cdot \cos a_{1}+P_{2} \cdot \cos a_{2}$

(2)

なお，本モデルにおいては以下のように荷重 点 $\mathrm{B}$ を境にして区間 $\mathrm{AB}$ と区間 $\mathrm{BC}$ で異なる変 形理論式が導かれる.

\section{1 区間 $A B$ に対する変形理論}

区間 $\mathrm{AB}$ のはりの長さを $L$ ，点 $\mathrm{B}$ におけるモ ーメントを $M_{B}$ とすれば,たわみ曲線上の任意点

$(x, y)$ に作用する曲げモーメント $M$ は

$M=-P \cdot x+P_{H} \cdot y=-P_{v} L \cdot \xi+P_{H} L \cdot \eta$

ここで,

$\zeta=s / L, \quad \xi=x / L, \quad \eta=y / L, \quad \delta=l / L$,

$\left.\lambda_{1}=P_{1} L^{2} /(E I), \lambda_{2}=P_{2} L^{2} /(E I), \beta=M_{B} L /(E I)\right\}$

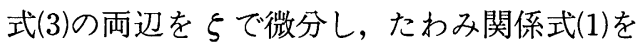
考慮すれば

$d^{2} \theta / d \zeta^{2}+\lambda \cdot \sin (\theta-a)=0$

$\lambda=\sqrt{\lambda_{1}{ }^{2}+2 \lambda_{1} \lambda_{2} \cdot \cos \left(a_{1}-a_{2}\right)+\lambda_{2}{ }^{2}}$

$a=\operatorname{Arctan}\left(\frac{\lambda_{1} \cdot \sin a_{1}+\lambda_{2} \cdot \sin \alpha_{2}}{\lambda_{1} \cdot \cos a_{1}+\lambda_{2} \cdot \cos \alpha_{2}}\right)$

さらに，点 $\mathrm{B}$ における境界条件 $\left.(d \theta / d \zeta)\right|_{\theta=\theta_{s}}=$ $M_{B} L /(E I)=-\beta$ より, 最終的に

$d \theta / d \zeta= \pm \sqrt{2 \lambda\left\{\cos (\theta-a)+\beta^{2} /(2 \lambda)-\cos \left(\theta_{B}-a\right)\right\}}$

なお，右辺の正負符号 $( \pm)$ は，無次元円弧長 さ $\xi$ に対したわみ角 $\theta$ が増加する区間で正, 減 少する区間で負を採用する，ところで，本論文 においては変曲点 D が存在する場合のみの理論 計算式を示すこととする。

微分方程式(8)の理論解析にあたり

$$
k=\sqrt{\left[2 \lambda \cdot\left\{1-\cos \left(\theta_{B}-\alpha\right)\right\}+\beta^{2}\right] / \lambda} / 2
$$

$1-\cos (\theta-a)=2 k^{2} \cdot \sin ^{2} \phi$

（ただし, $-\pi / 2 \leqq \phi \leqq \pi / 2)$

を導入すれば, 微小量 $d \xi, d \xi, d \eta$ は

$d \zeta= \pm d \phi /\left(\sqrt{\lambda} \cdot \sqrt{1-k^{2} \sin ^{2} \phi}\right)$

[-:区間 $\mathrm{AD},+$ :区間 $\mathrm{DB}]$

$$
\begin{aligned}
& d \xi= \pm 1 / \sqrt{\lambda}\{-2 k \cdot \sin a \cdot \sin \phi \\
& \left.+\cos a \cdot\left(2 \sqrt{1-k^{2} \cdot \sin ^{2} \phi}-1 / \sqrt{1-k^{2} \cdot \sin ^{2} \phi}\right)\right\} \cdot d \phi \\
& \quad[-: \text { 区間 } \mathrm{AD},+: \text { 区間 } \mathrm{DB}] \cdots \cdots \cdots \cdots \cdots(12)
\end{aligned}
$$

$$
\begin{aligned}
& d \eta= \pm 1 / \sqrt{\lambda}\{2 k \cdot \cos \alpha \cdot \sin \phi \\
& \left.+\sin \alpha \cdot\left(2 \sqrt{1-k^{2} \cdot \sin ^{2} \phi}-1 / \sqrt{1-k^{2} \cdot \sin ^{2} \phi}\right)\right\} \cdot d \phi \\
& \quad[-: \text { 区間 } \mathrm{AD},+: \text { 区間 } \mathrm{DB}] \ldots \ldots \ldots \ldots \ldots \ldots(13)
\end{aligned}
$$

ここで，新しい角度変数 $\phi$ は

$$
\begin{gathered}
\phi= \pm \operatorname{Arcsin}\left\{\sqrt{\frac{2 \lambda \cdot\{1-\cos (\theta-a)\}}{2 \lambda \cdot\left\{1-\cos \left(\theta_{B}-a\right)\right\}+\beta^{2}}}\right\} \cdots \cdot(14) \\
{\left[\begin{array}{ccc}
+: & 0 \leqq \theta-a \leqq \pi & , \quad 0 \leqq \phi \leqq \pi / 2 \\
-: & -\pi \leqq \theta-a \leqq 0, & -\pi / 2 \leqq \phi \leqq 0
\end{array}\right]}
\end{gathered}
$$

したがって，式(11)を角度変数 $\phi_{A} \sim \phi$ (実角度 $\theta_{A} \sim \theta$ に対応)にわたって積分すれば，はりのた わみ曲線上の任意点までの無次元円弧長さ $\xi$ を 求めることができ, 変曲点 $\mathrm{D}$ を境に 2 つの解析 式が導かれる. 角度変数 $\phi_{A^{\prime}}, \phi_{D}$ について, 回転 自由端 $A$, 変曲点 $D$ において $\left.(d \theta / d \zeta)\right|_{\theta=\theta_{\Lambda}}=\left.(d \theta / d \zeta)\right|_{\theta=\theta_{0}}=0$, すなわち

$\phi_{A}=\pi / 2, \quad \phi_{D}=-\pi / 2$

なる条件を考慮すれば

$$
\zeta=\int_{\phi_{1}}^{\phi} d \zeta=\{K(k)-F(k, \phi)\} / \sqrt{\lambda} \ldots \ldots \ldots \ldots \ldots(16)
$$

[区間 AD]

$$
\zeta=\int_{\phi_{1}}^{\phi_{c}} d \zeta+\int_{\phi_{c}}^{\phi} d \zeta=\{3 K(k)+F(k, \phi)\} / \sqrt{\lambda} \cdots \cdots(17)
$$

[区間 DB] 
同様にして，たわみ曲線上の任意点までの無次 元水平距離 $\xi$ は, 式(12)上り

$$
\xi=-\left\{2 k \cdot \sin \alpha \cdot \cos \phi+\cos \alpha \cdot \Phi_{1}(\phi)\right\} / \sqrt{\lambda}
$$

[区間 $\mathrm{AD}$ ]

$$
=\left\{2 k \cdot \sin \alpha \cdot \cos \phi+\cos \alpha \cdot \Phi_{2}(\phi)\right\} / \sqrt{\lambda}
$$

ここで,

[区間 DB]

$$
\Phi_{1}(\phi)=\{K(k)-F(k, \phi)\}-2\{E(k)-E(k, \phi)\}
$$

$\Phi_{2}(\phi)=-\{3 K(k)+F(k, \phi)\}+2\{3 E(k)+E(k, \phi)\}$

なお， $F(k, \phi), E(k, \phi) は$ Legendre-Jacobi の不完全だ円積分第一種，第二種， $K(k), E(k)$ は完全だ円積分第一種，第二種を表す。

さらに，たわみ曲線上の任意点における無次 元垂直距離 $\eta$ は, 式(13)より

$$
\eta=\left\{2 k \cdot \cos a \cdot \cos \phi-\sin \alpha \cdot \Phi_{1}(\phi)\right\} / \sqrt{\lambda}
$$

$$
\text { [区間 } \mathrm{AD} \text { ] }
$$

$=\left\{-2 k \cdot \cos \alpha \cdot \cos \phi+\sin \alpha \cdot \Phi_{2}(\phi)\right\} / \sqrt{\lambda}$

$$
\text { [区間 DB] }
$$

ところで，はりの変形後のたわみ曲線におけ る円弧長さ $s_{B}$ は, $\mathrm{AB}$ 間のはり長 $L$ に等しく, 式(17)において $\phi=\phi_{B} て ゙ \xi_{B}\left(=s_{B} / L\right)=1$ なる条件 より，合成荷重パラメータ $\lambda$ は

$$
\lambda=\left\{3 K(k)+F\left(k, \phi_{B}\right)\right\}^{2}
$$

したがって，点 $\mathrm{B}$ までの無次元水平距離

$$
\begin{aligned}
& \xi_{B}\left(=\left.\xi\right|_{\phi=\phi_{n}}\right) \text { は } \\
& \xi_{B}=\frac{2 k \cdot \sin \alpha \cdot \cos \phi_{B}+\cos \alpha \cdot \Phi_{2}\left(\phi_{B}\right)}{3 K(k)+F\left(k, \phi_{B}\right)} .
\end{aligned}
$$

点 $\mathrm{B}$ における無次元垂直距離 $\eta_{B}\left(=\left.\eta\right|_{\phi=\phi_{n}}\right)$ は

$$
\eta_{B}=\frac{-2 k \cdot \cos \alpha \cdot \cos \phi_{B}+\sin \alpha \cdot \Phi_{2}\left(\phi_{B}\right)}{3 K(k)+F\left(k, \phi_{B}\right)}
$$

\section{2 区間 BC に対する変形理論}

区間 $\mathrm{BC}$ のたわみ曲線上の任意点 $(x, y)$ に作用 する曲げモーメント $M$ は

$$
\begin{aligned}
M=-P_{V} \cdot x+P_{H} \cdot y+P_{1} \cdot\left(x-x_{B}\right) \cdot \sin \alpha_{1} \\
-P_{1} \cdot\left(y-y_{B}\right) \cdot \cos a_{1}
\end{aligned}
$$

$$
=-L P_{2} \cdot \sin a_{2} \cdot \xi+L P_{2} \cdot \cos a_{2} \cdot \eta
$$$$
-P_{1} \cdot\left(x_{B} \cdot \sin a_{1}-y_{B} \cdot \cos a_{1}\right) \cdots \cdots \cdot(25)
$$

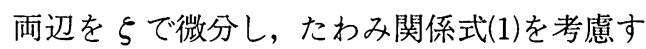
れば

$d^{2} \theta / d \zeta^{2}+\lambda_{2} \cdot \sin \left(\theta-a_{2}\right)=0$ $\cdot(26)$

点 Cにおける境界条件

$\left.(d \theta / d \zeta)\right|_{\theta=\theta_{c}}=-M c L /(E I)=0$ より, 最終的に 次式が導かれる。

$d \theta / d \zeta= \pm \sqrt{2 \lambda_{2}\left\{\cos \left(\theta-a_{2}\right)-\cos \left(\theta_{c}-a_{2}\right)\right\}} \cdots(27)$

ここで，右辺の正負符号 $( \pm)$ は，無次元円弧 長さ $\xi$ に対し,たわみ角 $\theta$ が増加する区間で正, 減少する区間で負を採用する。なお，本論文に おいては区間 $\mathrm{BC}$ に変曲点が存在しない場合のみ の理論計算式を示すこととする。

微分方程式(27)の理論解析にあたり

$$
q=\sqrt{\left\{1-\cos \left(\theta_{c}-a_{2}\right)\right\} / 2}
$$

$$
1-\cos \left(\theta-a_{2}\right)=2 q^{2} \cdot \sin ^{2} \psi
$$

（ただし, $-\pi / 2 \leqq \psi \leqq \pi / 2)$

を導入すれば，はりのたわみ曲線上の任意点ま での無次元円弧長さ $\xi$, 無次元水平距離 $\xi$, 無次 元垂直距離 $\eta$ はそれぞれ次のように求めること ができる.

$$
\begin{aligned}
\zeta & =\int_{\phi_{1}}^{\phi_{1}} d \zeta+\int_{\psi_{1}}^{\varphi} d \zeta \\
& =1 \pm\left\{F(q, \varphi)-F\left(q, \varphi_{B}\right)\right\} / \sqrt{\lambda_{2}}
\end{aligned}
$$

$\xi=\xi_{B} \pm\left\{2 q \cdot \sin \alpha_{2} \cdot\left(\cos \psi-\cos \psi_{B}\right)\right.$

$$
\left.+\cos a_{2} \cdot \Phi_{3}(\psi)\right\} / \sqrt{\lambda_{2}}
$$


$\eta=\eta_{B} \pm\left\{-2 q \cdot \cos \alpha_{2} \cdot\left(\cos \psi-\cos \psi_{B}\right)\right.$

ここで,

$$
\left.+\sin a_{2} \cdot \Phi_{3}(\Psi)\right\} / \sqrt{\lambda_{2}} \cdots(32)
$$

$$
\begin{aligned}
\Phi_{3}(\psi)=\left\{F\left(q, \Psi_{B}\right)\right. & F(q, \Psi)\} \\
& -2\left\{E\left(q, \Psi_{B}\right)-E(q, \Psi)\right\}
\end{aligned}
$$

また，角度変数

$$
\begin{aligned}
& \psi= \pm \operatorname{Arcsin}\left\{\sqrt{\frac{1-\cos \left(\theta-a_{2}\right)}{1-\cos \left(\theta_{c}-a_{2}\right)}}\right\}
\end{aligned}
$$

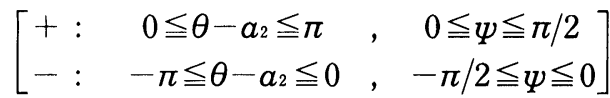

ところで，はりの変形後のたわみ曲線におけ る円弧長さ $s_{\text {は }}$, はり長 $(L+l)$ に等しく，すなわ ち式(30)において $\psi=\psi_{c} て ゙ \xi_{C}\left(=s_{C} / L\right)=1+\delta な$ る条件より，荷重パラメータ $\lambda_{2}$ は

$$
\lambda_{2}=\left[\left\{F\left(q, \psi_{c}\right)-F\left(k, \psi_{B}\right)\right\} / \delta\right]^{2}
$$

なお，角度変数 $\psi_{c}$ (たわみ角 $\theta_{c}$ に対応) は，自由 端 $\mathrm{C}$ で $\left.(d \theta / d \zeta)\right|_{\theta=\theta_{c}}=0$ なる条件より

$$
\psi c= \pm \pi / 2
$$

したがって，式(34)は

$\lambda_{2}=\left[\left\{ \pm K(q)-F\left(k, \Psi_{B}\right)\right\} / \delta\right]^{2}$

また，自由端 $\mathrm{C}$ までの無次元水平距離 $\xi_{c}$ は

$\xi_{c}=\xi_{B} \pm \frac{-2 q \cdot \sin \alpha_{2} \cdot \cos \psi_{B}+\cos a_{2} \cdot \Phi_{3}\left(\psi_{c}\right)}{ \pm K(q)-F\left(q, \Psi_{B}\right)} \delta \cdots(37)$

自由端 Cにおける無次元垂直距離 $\eta_{c}$ は

$$
\eta_{c}=\eta_{B} \pm \frac{2 q \cdot \cos \alpha_{2} \cdot \cos \psi_{B}+\sin \alpha_{2} \cdot \Phi_{3}\left(\Psi_{c}\right)}{ \pm K(q)-F\left(q, \Psi_{B}\right)} \delta \cdots(38)
$$

\section{3. 大たわみポールモデルの数値計算例}

Fig. 4 は, 各種のモーメント $(\beta)$ を受けたとき の, 区間 $\mathrm{AB}$ の無次元弦長 $\omega_{\mathrm{B}}\left(=W_{\mathrm{B}} / L=\right.$ $\left.\sqrt{\xi_{\mathrm{B}}{ }^{2}+\eta_{\mathrm{B}}{ }^{2}}\right)$ に対する無次元荷重パラメータ $\lambda$, すなわち跳躍者がポールに負荷する二つの荷重 の合力の関係を表したものである (Fig. 3 参照).

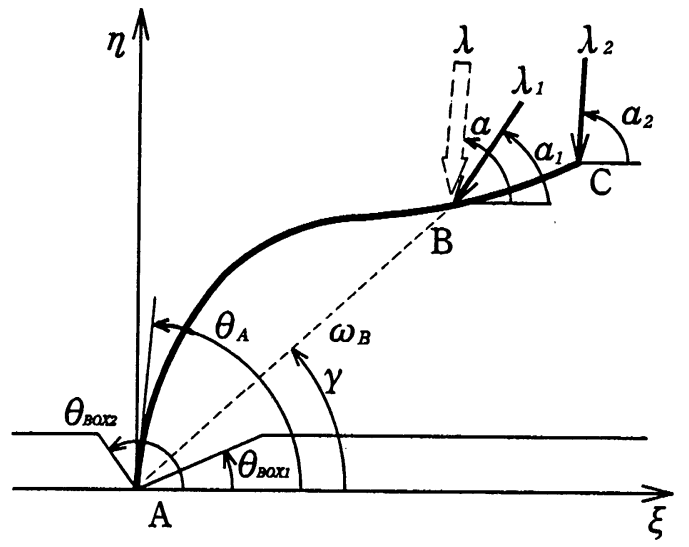

Fig. 3 Schematic configuration of pole-vaulting

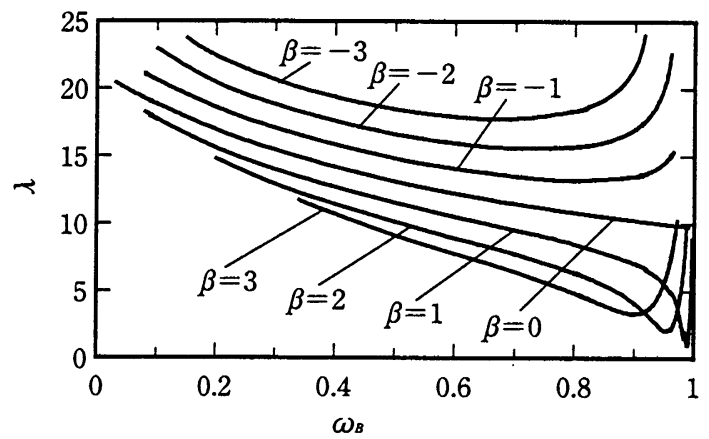

Fig. 4 Variation of load parameter $\lambda$ with nondimensional chord length $\omega_{B}$

点 $\mathrm{B}$ でのモーメントが $0(\beta=0)$ のとき，ポール はオイラ一座屈荷重 $\left(\lambda_{\text {Euler }}=\pi^{2}=9.87\right)$ で変形が

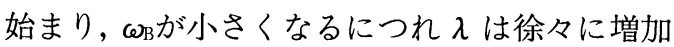
する。なお，いずれのモーメント（土）が存在 する場合にも下に凸の変化傾向を示す．また， モーメントが負の場合には，粗が大きい場合も ポールを変形させるためには大きな $\lambda$ が必要と なることが分かる。

Fig. 5 は, 各種のモーメント $(\beta)$ を受けたとき の, 区間 $\mathrm{AB}$ の無次元弦長 $\omega_{B}$ に対する合成荷重 の角度パラメータ $\alpha^{\prime}(=\alpha-\gamma)$ の関係を表したも ので， $\alpha^{\prime}$ はポールの区間 $\mathrm{AB}$ の弦と合成荷重 $\lambda$ のなす角度（Fig. 3 参照）である。点 B でのモ

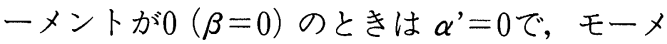
ントが負の場合は $\alpha^{\prime}$ は正值をとり，ポールが変 


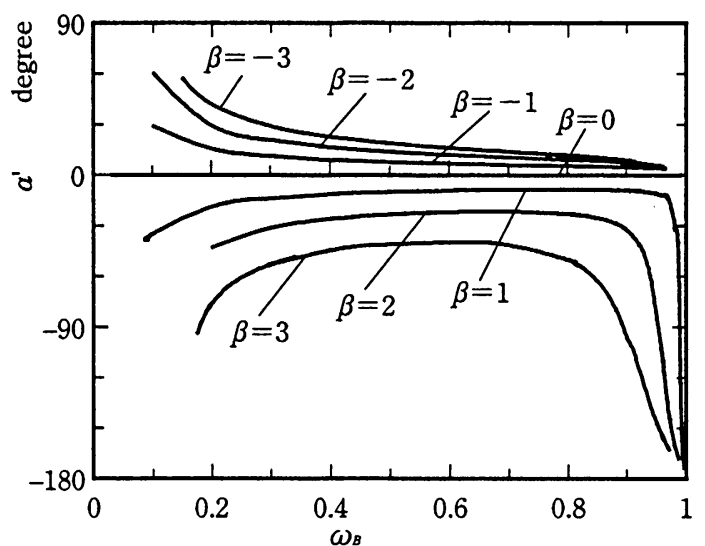

Fig. 5 Variation of angle parameter $\alpha$ ' with nondimensional chord length $\omega_{3}$

形するに伴い漸增する。一方，モーメントが正 の場合には $\alpha^{\prime}$ は負值で, 上に凸の変化傾向を示 す。ところで，回転自由端としたボックス内の 点 A では，ポールに対して圧縮荷重のみが作用 するため, 角度パラメータ $\alpha^{\prime}$ 範囲は

$\theta_{\text {BOX } 2}-180^{\circ}-\gamma \leq a^{\prime} \leq \theta_{\text {BOX } 1}+180^{\circ}-\gamma$ $\cdot(39)$

$\left(\theta_{\text {вох1 } 1}=11.6^{\circ}, \quad \theta_{\text {вох } 2}=116.6^{\circ}\right)$

に限られる。したがって，この範囲外は棒高跳 びには不適切な領域であり, 特に, $\alpha$ が小さな 值(負), すなわち区間 $\mathrm{AB}$ の変形量がきわめて 小さな範囲ではポールの点 $\mathrm{B}$ に正のモーメント が現れるような負荷はできないと言える.

Fig. 6 は,ポールの各種変形状態を表したもの で, $\eta_{3}=0, \delta=0.1$ とし, 区間 BCには変曲点は 現れない場合を例示した。ポールの形状は $\beta>0$

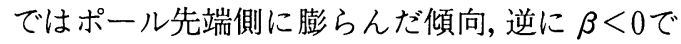
はポールの区間 $\mathrm{AB} に$ 変曲点が現れ, かつポー ルの支点側に膨らんだ傾向を示す. $\beta=0$ の場合 は, 図中の Case $\mathrm{a} \sim$ Case $\mathrm{c}$ の変形が現れ, 点 $\mathrm{B}$ が変曲点となるような状態 (Case c) も存在す る. Case a の状態は点 B のみへの負荷 $\left(\lambda_{2}=0\right)$ の場合であり，このとき， $\lambda_{1}=\lambda, \alpha_{1}=0^{\circ}$ となり， 区間 BC は変形しない. Case b, Case c はそれ ぞれ $\lambda_{1}=2997, \alpha_{1}=0^{\circ}, \lambda_{2}=2985, \alpha_{2}=-180^{\circ}$ と $\lambda_{1}=1240, \alpha_{1}=-180^{\circ}, \lambda_{2}=1252, \alpha_{2}=0^{\circ}$ の場合
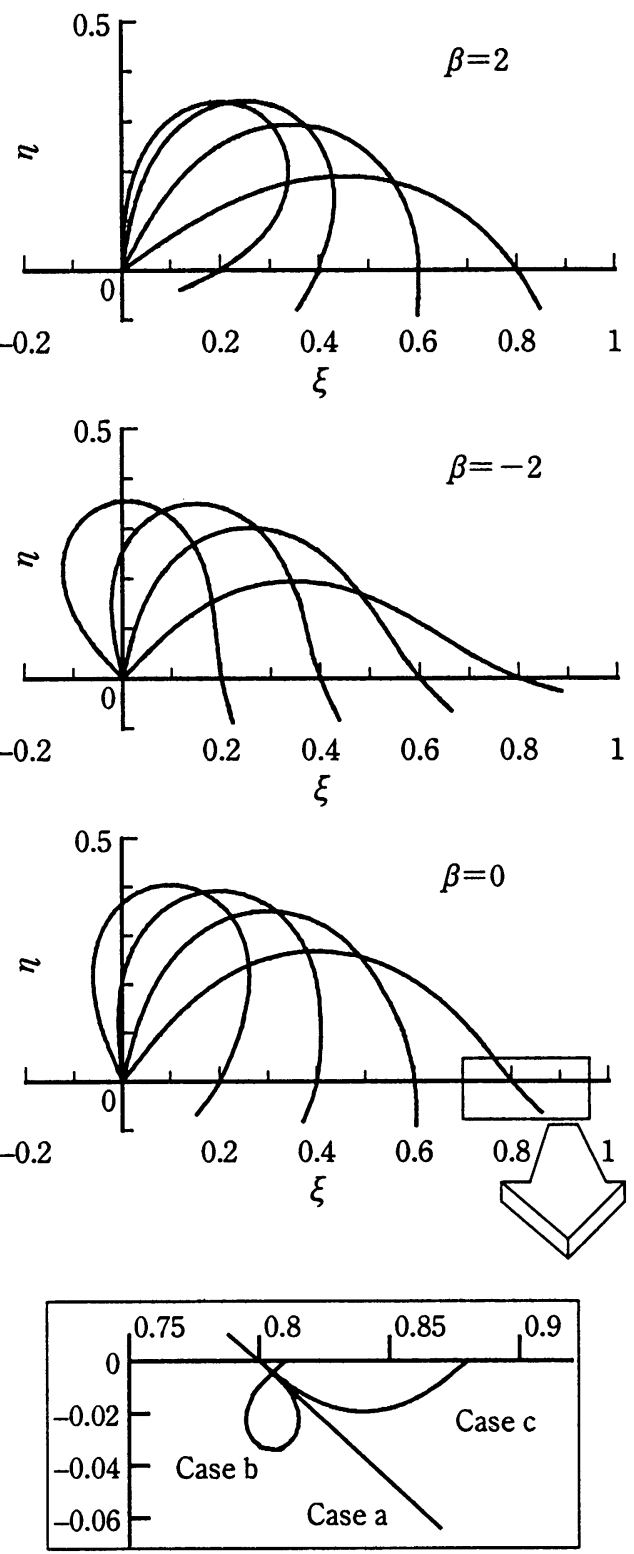

Fig. 6 Some examples of pole deformation

$$
\left[\eta_{3}=0, \delta=0.1\right]
$$

であり，どちらも荷重パラメータ $\lambda_{1}, \lambda_{2}$ が非常 に大きく，棒高跳びを扱う際には不適当である と考え,ここでは主に Case a の状態について図 示してある。

Fig. 7 は, $\xi_{B}=0.8 て ゙$, 各種のモーメント $(\beta=$ 


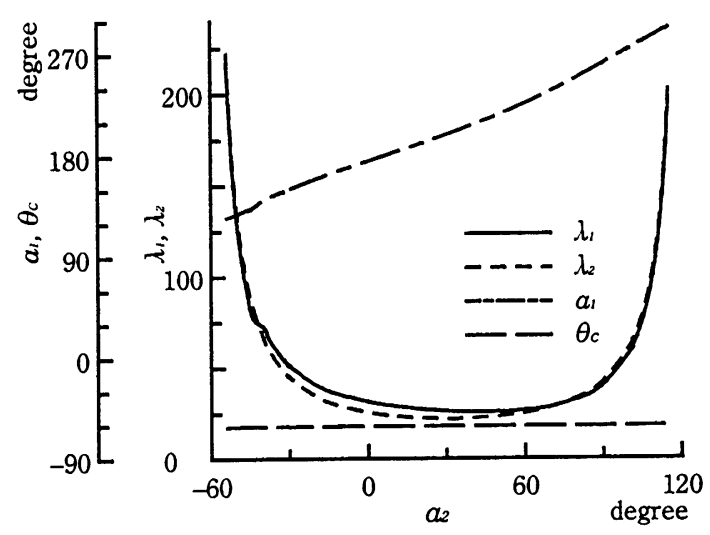

(a) $[\beta=2]$

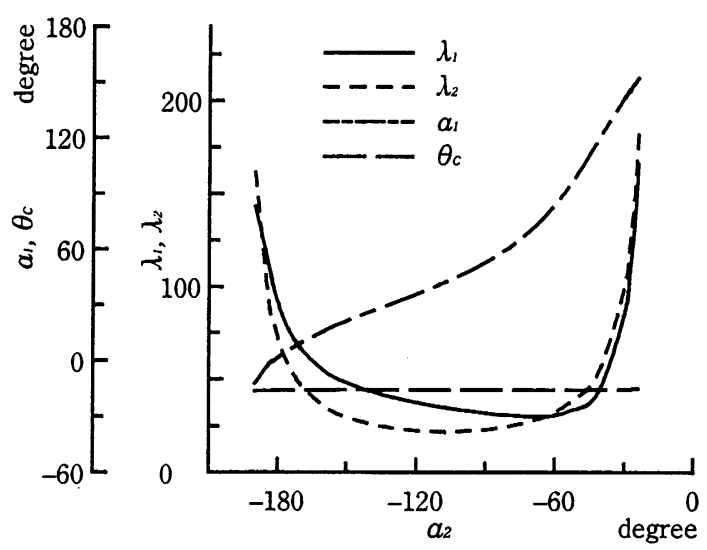

(b) $[\beta=-2]$

Fig. 7 Variation of load parameter $\lambda_{1}, \lambda_{2}$ and angle parameter $\alpha_{1}, \theta_{c}$ with angle parameter $\alpha_{2}$

$2,-2)$ を受けたときの, 荷重の角度パラメー 夕 $\alpha_{2}$ に対する荷重パラメータ $\lambda_{1}, \lambda_{2}$ 抢よび点 $\mathrm{B}$ の荷重角度パラメー夕 $\alpha_{1}$, 点 $\mathrm{C}$ のたわみ角 $\theta_{c}$ の

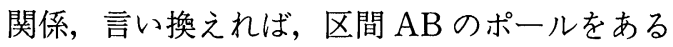
状態に保持する場合の荷重パラメー夕間の関係

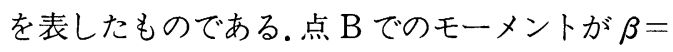
2 (Fig.a), $\beta=-2$ (Fig.b)のいずれの場合も, $\theta_{c}$ は $\alpha_{2}$ の変化に依らずほぼ一定值を示す.すなわち,

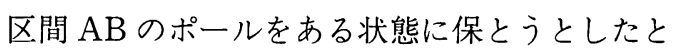
き,荷重パラメータの変化に関わらず区間 $\mathrm{BC} の$ ポールもほぼ一定の変形状態に保たれることを 意味する。また， $\alpha_{2}$ が $\theta_{c}$ あるいは $\theta_{c} \pm 180^{\circ}$ に近づ くにつれて $\lambda_{1}, \lambda_{2}$ が非常に大きくなる，下に凸 の変化傾向を示す。すなわち，ポールの接線方 向へは非常に大きな荷重を必要とし, 逆に垂直 方向には小さな荷重で良いことが分かる.

\section{4. 跳躍者モデル}

\section{1 運動方程式}

跳躍者の運動軌跡を求めるため, 次の跳躍者・ ポールシステムを仮定した。

1）跳躍者の運動をクロスバーに垂直な平面 上に限定する。

2 ）跳躍者をポールの支点側荷重点 Bに集中 した質点と見なす。

3）ポールの質量は無視する.
点 Bに質点として存在する跳躍者はポールか ら角度 $\alpha$ をなす集中荷重 $P\left[=\lambda \cdot\left(E I / L^{2}\right)\right]$ を 受けると考之られ, 跳躍者の質量を $m$, 重力加 速度を $g$, 加速度の水平方向成分を $\ddot{x}$, 垂直方向 成分を $\ddot{y}$ とすれば，運動方程式は次の形で与え られる。

$$
\left.\begin{array}{l}
m \cdot \ddot{x}+P \cdot \cos a=0 \\
m \cdot \ddot{y}+P \cdot \sin a+m \cdot g=0
\end{array}\right\} \cdots \cdots \cdots \cdots \cdots \cdots \cdots \cdot(40)
$$

式(40)は跳躍者がポールを保持している状態， ポールを離して空中にいる状態 $\left(P_{1}=P_{2}=0\right)$ の双 方で成立する。なお, 跳躍者がポールを保持し ている場合には, 跳躍者の軌跡と点 $\mathrm{B}$ の軌跡は 等しく 用いることができる。

\section{2 跳翟者モデルの計算例}

跳躍者の運動をシミュレートするに際し，ポ 一ルの曲げ剛性 $E I$ と跳躍者質量 $m$ の比を $\mu=$ $E I / m$ とおき,式(40)に 4 次の Runge Kutta 法を 適用し, 時間ステップ幅 0.02 秒, 重力加速度 $g=$ $9.81\left[\mathrm{~m} / \mathrm{s}^{2}\right]$ として計算した。 なお，初期垂直 および水平速度は，ポール先端がボックスに当 たる瞬間 (PP 時)の速度であり，1991年東京世 界陸上競技の平均值を採用した。 


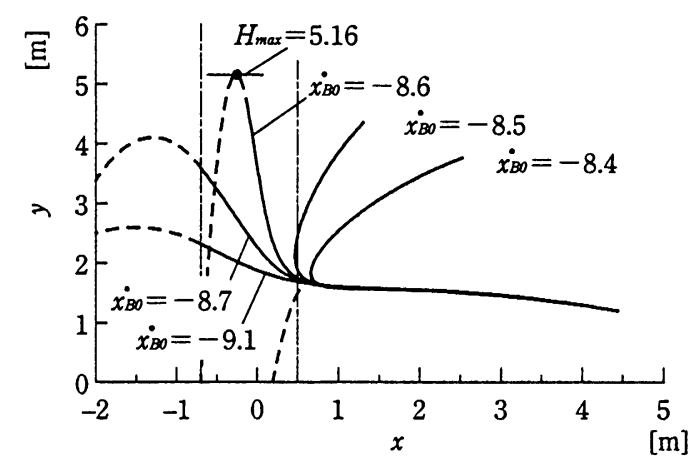

Fig. 8 Trajectories of vaulter $\left[\dot{y}_{B O}=2.0[\mathrm{~m} / \mathrm{s}]\right.$, $\mu=21.0, \quad L=4.6, \quad \beta=0]$

Fig. 8 は, 区間 $\mathrm{AB}$ のポール長を $L=4.6[\mathrm{~m}]$, ポールの曲げ剛性 $E I$ と跳躍者質量 $m$ の比を $\mu=21.0\left[\mathrm{~N} \cdot \mathrm{m}^{2} / \mathrm{kg}\right]$, 曲げモーメントを $\beta=0$ と L, 初期座標 $\left(x_{B O}, y_{B O}\right)=(4.44[\mathrm{~m}], 1.2[\mathrm{~m}])$, 初期垂直方向速度 $\dot{y}_{B O}=2.0[\mathrm{~m} / \mathrm{s}]$ としたときの, 各種の初期水平方向速度 $\dot{x}_{B O}$ に対する跳躍者の跳 躍軌跡 $y$ を示したものである，ただし，図示し た実線の軌跡は跳躍者がポールを保持している 場合のもので，破線は跳躍者が実線で示した軌 跡上の各点でポールから離脱後に得られる跳躍 高さのうち, 最大の跳躍高さ $H_{\max }$ を得るときの ポール離脱後の軌跡を示している.なお, 跳躍 高さとはクロスバーを跳躍者が飛び越すときの 最大值を意味しているが, 棒高跳びのルールで は,クロスバーをボックス上縁から前後に $60[\mathrm{~cm}]$ 移動することが許されているため,ここではー70 $[\mathrm{cm}] \leq x \leq 50[\mathrm{~cm}]$ の範囲 (図中一点鎖線) で 最大をとる場合を考之た。図より，初期水平方 向速度 $\dot{x}_{B O}$ がー8.6[m/s] のときに最大の跳躍高 さ $H_{\max }=5.16[\mathrm{~m}]$ が得られ，これよりも小さ い（絶対値）初期方向速度では跳躍者はポール に跳ね返されてしまい，逆に大きい速度では， 高さが十分得られないうちにクロスバーの設置 できる跳躍範囲に到達してしまう。したがって， 初期水平方向速度は大きすぎても，小さすぎて もいけない適当な值が存在することが分かる.

Fig. 9 は, 各種の初期垂直方向速度 $\dot{y}_{B O}$ に対する 跳躍者の跳躍軌跡 $y$ を示したもので, 初期水平

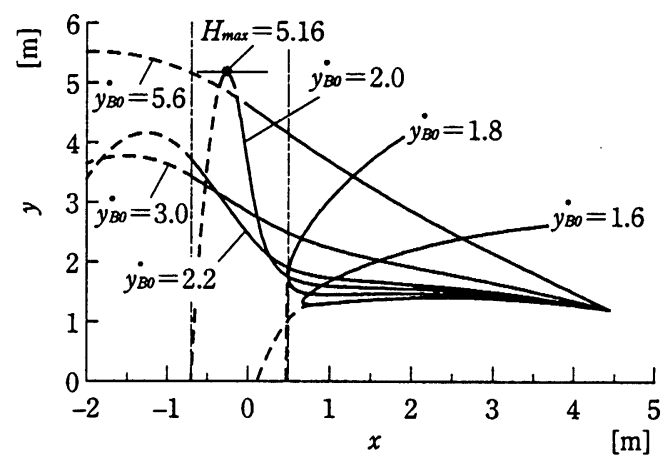

Fig. 9 Trajectories of vaulter $\left[\dot{x}_{B O}=-8.6[\mathrm{~m} / \mathrm{s}]\right.$, $\mu=21.0, \quad L=4.6, \quad \beta=0]$

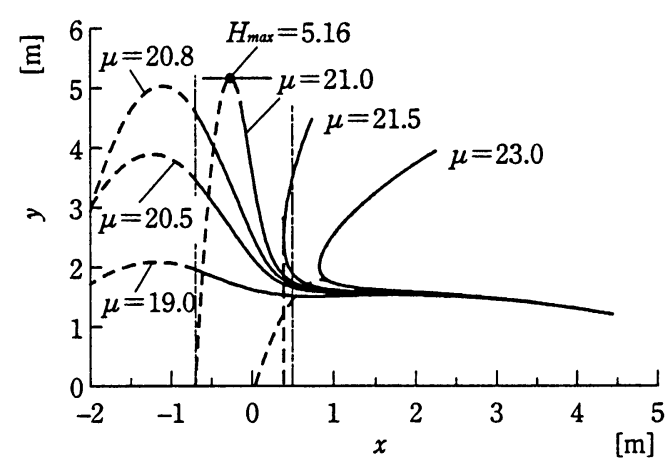

Fig. 10 Trajectories of vaulter $\left[\dot{x}_{B O}=-8.6[\mathrm{~m} / \mathrm{s}]\right.$, $\left.\dot{y}_{B O}=2.0[\mathrm{~m} / \mathrm{s}], L=4.6, \beta=0\right]$

方向速度 $\dot{x}_{B O}=-8.6[\mathrm{~m} / \mathrm{s}]$ とし，その他の条件 はFig. 8 と同様である. 図より $\dot{y}_{B O}=2.0[\mathrm{~m} / \mathrm{s}]$ のときに，最大跳躍高さ $H_{\max }=5.16[\mathrm{~m}]$ を得 ることができ，これより小さい值ではポールに 跳ね返されてしまい，図中の $2.2 \sim 5.6[\mathrm{~m} / \mathrm{s}]$ の 速度では高さが十分得られないうちにバーの跳 躍範囲に到達してしまうことが分かる。なお， $\dot{y}_{B O}=5.6[\mathrm{~m} / \mathrm{s}]$ を越える大きな垂直方向速度で ジャンプした場合は，より大きな跳躍高さが得 られるが,この範囲は一般の跳躍者の出しうる 能力を越えているのではないかと考えられる.

Fig.10は,種々のポールの曲げ剛性と跳躍者質 量の比 $\mu(=E I / m)$ に対する跳躍者の跳躍軌跡 $y$ を示したもので, 初期水平方向速度 $\dot{x}_{B O}=-8.6$ $[\mathrm{m} / \mathrm{s}]$ とし,その他の条件は Fig. 8 と同様であ 


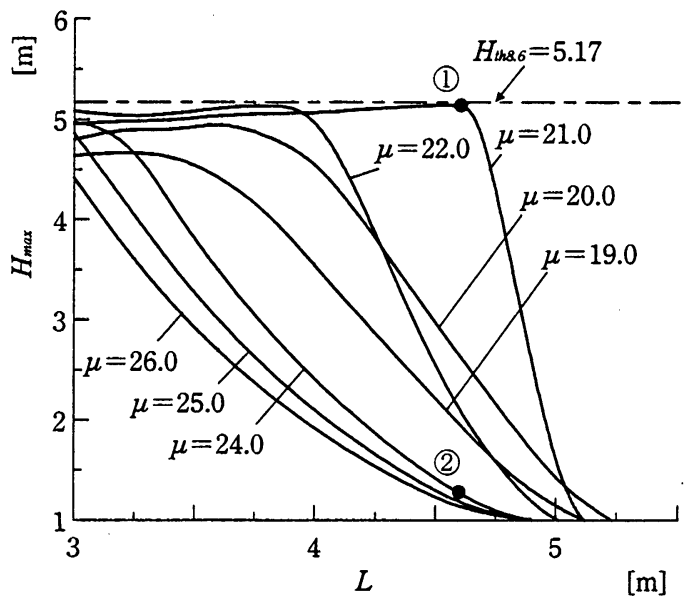

Fig. 11 Variation of maximum vaulting height $H_{\max }$ with length $L\left[\dot{x}_{B O}=-8.6[\mathrm{~m} / \mathrm{s}]\right.$, $\left.\dot{y}_{B O}=2.0[\mathrm{~m} / \mathrm{s}], \quad \beta=0\right]$

る.この場合も $\mu=21.0\left[\mathrm{~N} \cdot \mathrm{m}^{2} / \mathrm{kg}\right]$ のときに 最大跳躍高さ $H_{\max }=5.16[\mathrm{~m}]$ が得られること が分かる。

Fig.11は, 最大跳躍高さ $H_{\max }$ とポール長 $L$ と の関係を各種のポールの曲げ岡性と跳躍者質量 の比 $\mu$ に対して示したもので, 初期水平方向速 度 $\dot{x}_{B O}=-8.6[\mathrm{~m} / \mathrm{s}]$, 初期垂直方向速度 $\dot{y}_{B O}=$ $2.0[\mathrm{~m} / \mathrm{s}]$ とし, 初期位置は $y_{B O}=1.2[\mathrm{~m}]$ で ポールが真直な状態とした. 図中一点鎖線で示 した水平線は, $\mathrm{P} P$ 時の運動エネルギ一（水平 および垂直方向）がすべて位置エネルギーに変 換された場合の理論跳躍高さ $H_{t h 8.6}=5.17[\mathrm{~m}]$ を示している。 ポール(1) $(L=4.6, \mu=21.0) の$ 場合に最大跳躍高さ $H_{\max }=5.16[\mathrm{~m}]$ が得られ る.また， $\mu=21.0$ のとは， $L=4.6[\mathrm{~m}]$ 以下 のポールでも $H_{t h .6}$ とほぼ同じ跳躍高さが得られ， $L=4.6[\mathrm{~m}]$ を越えるポールでは跳躍高さが急 激に減少している。また，21.0よりも大きいあ るいは小さい $\mu$ の場合では $L=4.6[\mathrm{~m}]$ 付近で は十分な跳躍高さが得られないことが分かる。 ところで, $L=3.0[\mathrm{~m}]$ 付近ではいかなる $\mu$ に 対しても $H_{t h 8.6}$ に近い跳躍高さが原理的には得ら れるようであり，すなわち「抜き」の高さ（グ リップ高以上に重心が上昇した距離）にはポー

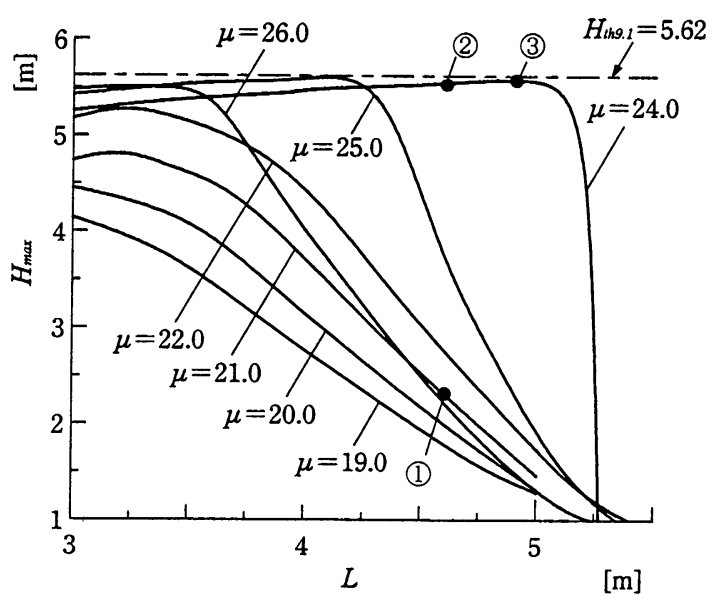

Fig. 12 Variation of maximum vaulting height $H_{\max }$ with length $L\left[\dot{x}_{B O}=-9.1[\mathrm{~m} / \mathrm{s}]\right.$, $\left.\dot{y}_{B O}=2.0[\mathrm{~m} / \mathrm{s}], \beta=0\right]$

ルの剛性が関係している7)だけでなく曲げ岡性と 跳躍者質量の比 $\mu$ およびポール長(グリップ高) $L$ に大きく関係していることが示唆される。こ れに対してFig.12は, 初期水平方向速度 $\dot{x}_{B O}=$ $-9.1[\mathrm{~m} / \mathrm{s}]$ としたときの, 最大跳躍高さ $H_{\max }$ とポール長 $L$ との関係を各種のポールの曲げ剛 性と跳躍者質量の比 $\mu$ に対して示したもので, その他の条件は Fig.11と同様である.Fig.11に比 べ初期水平方向速度がー $0.5[\mathrm{~m} / \mathrm{s}]$ 増すだけで 初期水平方向速度 $\dot{x}_{B O}=-8.6[\mathrm{~m} / \mathrm{s}]$ に対し最大 跳躍高さが得られたポール(1) $(L=4.6, \mu=21.0)$ では，もはや十分な跳躍高さが得られないこと が分かる.したがって，ポール長が $L=4.6[\mathrm{~m}]$ のままであれば曲げ剛性のより大きい $\mu=24.00$ ポール(2)を使うことによって, 理論跳躍高さ $H_{t h .1}=5.62[\mathrm{~m}]\left(>H_{t h .6}\right)$ に近い跳躍高さ $H_{\max }=$ $5.60[\mathrm{~m}]$ を獲得できる.さらに, この剛性 $(\mu=$ 24.0) の場合は $L=5.2[\mathrm{~m}]$ 以下では $H_{t h 9.1}$ に近 い跳躍高さが得られることが分かる。なお，同 じポール剛性で，長さを長くした，例えばポー ル(3) $(L=4.9, \mu=24.0)$ の場合も $H_{t h 9.1}$ と同程 度の跳躍高さが得られる。

Fig.13は, PP 時から最高跳躍高さまでの総時 間 $t_{v}$ とポールをリリースするまでの時間 $t_{r}$ をポー 


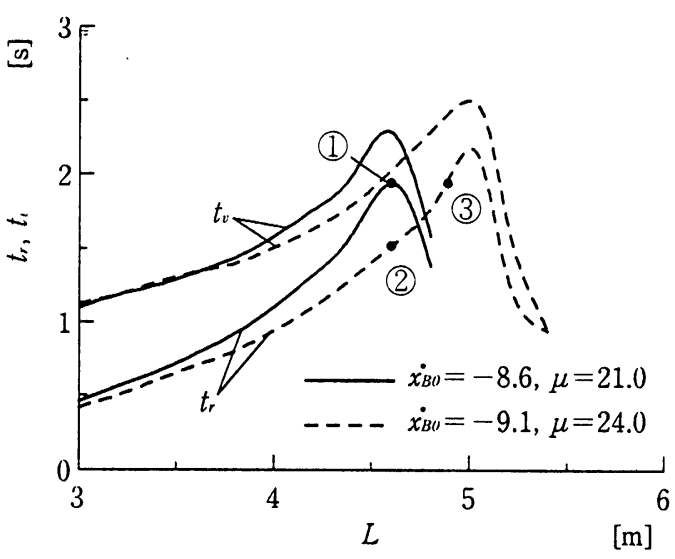

Fig. 13 Variation of vaulting time with length $L$ $\left[\dot{y}_{B O}=2.0[\mathrm{~m} / \mathrm{s}], \beta=0\right]$

ル長 $L$ に対して示したものである.ポール1 $(L=$ $4.6, \mu=21.0)$ で, 初期水平方向速度 $\dot{x}_{B O}=-8.6$ $[\mathrm{m} / \mathrm{s}]$ とした跳躍では $t_{r}=1.92[\mathrm{~s}]$, これに対 しポール(2) $(L=4.6, \mu=24.0)$ で，初期水平方 向速度 $\dot{x}_{B O}=-9.1[\mathrm{~m} / \mathrm{s}]$ とした跳躍では $t_{r}=$ $1.52[\mathrm{~s}]$ を要している。すなわち，初期水平方 向速度 (絶対值) が増したとき，ポール長を変 えずにポールの曲げ剛性を大きくすることだけ で跳躍高さを増加させようとすると，ポールリ リースまでの時間 $t$ が短くなることを示している。 このことは，より短時間にリリースまでの動作 を完了しなければいけないことになり，跳躍テ クニックの大幅な改良が必要となることが予想 される。したがって，リリースまでの時間を同 じようにするためには，ポール長を大きくした ポール(3) $(L=4.9 ， \mu=24.0)$ を使用すれば良い ことが分かる。

Fig.14は, 跳躍者の最大合成加速度 $a_{\max }(=$ $\left.\operatorname{Max}\left(\sqrt{\ddot{x}_{B}{ }^{2}+\ddot{y}_{B}{ }^{2}}\right)\right)$ をポール長 $L$ に対して示した もので，ポール長が増すと減少し，一方，初期 水平方向速度 $\dot{x}_{B O}$ が大きく, ポールの曲げ剛性と 跳躍者質量の比 $\mu$ も大きい方が大となる傾向に なることが分かる．この最大加速度は P P 時の 直後に現れるもので，ポールをボックスに突い たときの衝撃に大いに関連すると考えられるた め，この数值はできるだけ小さい方が良く，す

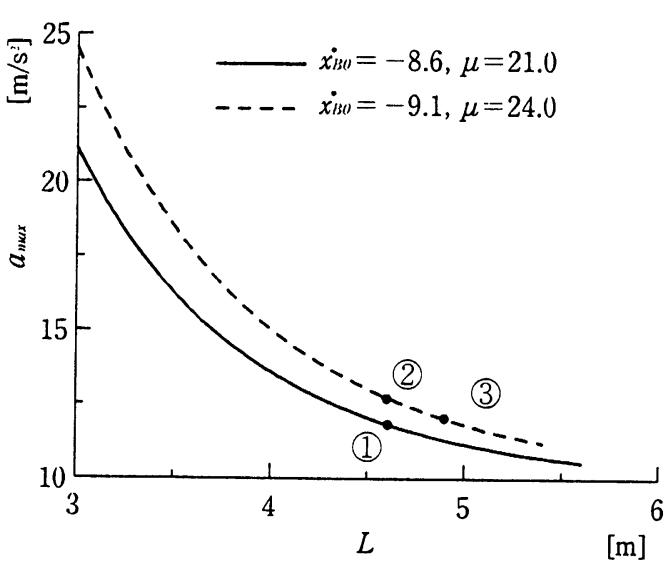

Fig. 14 Variation of maximum acceleration with length $L\left[\dot{y}_{B O}=2.0[\mathrm{~m} / \mathrm{s}], \quad \beta=0\right]$

なわち，この例で言うとポール(2)よりポール(3) の方が衝撃が小さくなることを示している.

\section{5.むす び}

本論文では，棒高跳びポールを二つの集中荷 重のみが負荷された大たわみはりとしてモデル 化し，ポールに作用する負荷とポール変形の関 係を非線形解析するとともに，跳躍者の運動に ついて簡単なモデルを構築し，跳躍高さに及ぼ すポール性能 (長さ, 剛性), 跳躍者能力 (走力 等）などの影響について動力学的な解析を行っ た.

以上の解析の結果, 次の諸点が明らかとなった.

（1）支点（点 A）から支点に近い荷重点（点 B）までの変形は，二つの集中荷重の合力と モーメントが同時に作用したとして扱うこ とができる。

（2）支点（点 A）から支点側の荷重点（点 B) までのポールを変形させるための合力は, 同じ変形量に対しては，モーメントが小さ い（負も含めて）方が大きい.すなわち， ポールに変曲点が現れるような負のモーメ ントをかけた場合の方がポールから大きな 反力を得ることができる (Fig. 4 参照).

(3) ポールを変形させる力はモーメントが零 の時を除いて, 正負いかなるモーメントが 
作用したとしても，変形量に対して下に凸 の変化傾向を示す (Fig. 4 参照).

（4）二つの荷重 $\left(P_{1}, P_{2}\right)$ は, その荷重方向が荷重 点でのポールの接線方向に近くなるにつれ て大きくなる，逆に，垂直方向の場合は小 さくなる (Fig. 7 参照).

（5）荷重点間に変曲点が生じない場合でも， 支点側の荷重点でのモーメントが零の場合, 荷重点間に 3 つの変形状態がある(Fig. 6 参 照).

（6）ある特定のポールを用いた場合, 跳躍高 さを獲得するための跳躍者の走力等には, 適当な值が存在する. したがって, その值 は大きければ良いというものではない(Fig. 8 参照).

（7）跳躍者の体重, 走力等が決まっていれば, そのときに最大の跳躍高さを得ることので きる適当なポール剛性が存在する (Fig. 9 ， 10，11，12参照).

（8）走力が向上した場合は，より剛性の大き い長いポールを使うことによってリリース 時間および最大加速度をほぼ一定に保つこ
とができる (Fig.13，14参照).

本研究の一部は文部省科学研究費・基盤研究 (C)（課題番号09680133）の援助を得たことを付 記する。

\section{参 考 文 献}

1) C.J.Dillman, J. Biomechanics, 1(1968), 175-183.

2) M. Buczek, Cz. II. Wlasnosci mechaniczen tyczki.Raort MINS/PNT/8/77, Warszawa, sierpien (1977) .

3) J. Morawski, Wychowanie Fizycze I Sport, 22 (1978), 43-61 .

4) M.Hubbard, Trans. ASME, J. Applied Mechanics, 47(1980), 200-202.

5 ) G.M.Griner, J. Applied Mechanics, 51(1984), 409 -414 .

6) 大槻敦巳, 大島成通, スポーツ工学シンポジウム，97 -10-2 (1997), 156-161.

7 ）淵本・ほか 3 名,「動きとスポーツの科学」，(1992）, 276-281. 